\title{
SOCIAL ENTREPRENEURSHIP AS AN OPPORTUNITY TO MODEL AN ACTIVE SOCIAL PROGRAM
}

\author{
Venelin Terziev \\ Professor, Ph.D., D.Sc. (National Security), D.Sc. (Ec.), University of Rousse, Rousse, Bulgaria, \\ National Military University, Veliko Tarnovo, Bulgaria, University of Telecommunications and Post, \\ Sofia, Bulgaria, terziev@skmat.com
}

\begin{abstract}
In contemporary society one of the priorities for development is to assure social inclusion and equality through provision of employment opportunities and increasing incomes by the active involvement of citizens in the labor market. Among the specific measures is the encouragement of entrepreneurship and social entrepreneurship in particular. Implementation of such active social policies contributes to effective solutions to the problems of poverty and social exclusion. Current study examines social entrepreneurship and social enterprises as an opportunity to build a model of an active social program based on the notion that the most critical to tackling poverty and social exclusion is the application of such social policies that give people access to economic opportunities and knowledge and skills to utilize opportunities - so that they cope with the trap of poverty and social exclusion, dependence on social protection system, vulnerability to the adverse events of economic or social nature.
\end{abstract}

Keywords: social entrepreneurship, social enterprise, active social program.

\section{INTRODUCTION}

In the last decade the concept of development and promotion of social economy and social entrepreneurship are part of EU policy to tackle the social exclusion of persons in a vulnerable position. Also, the model of social economy is one of the key instruments for achieving social objectives within the framework of the sustainable and inclusive growth (2016a). The promotion of innovative ideas in public policy is crucial to support the values of an active-oriented problem solving social system. These views underlie the ongoing social reforms in various countries and focus on the development of social entrepreneurship and the role of social entrepreneurs. An understanding is underlined that namely social entrepreneurs have the capability through localization of usable resources - human capital, buildings and equipment, to find flexible approaches to satisfy unmet social needs (2011b). Social entrepreneurship is identified at European Union (EU) as a key instrument for regional cohesion and overcoming the problems of poverty and social 
exclusion. As part of its policy to promote the social economy and social innovation, social entrepreneurship contribute to achieving the strategic goals set in 2020 (2016b).

The social economy develops through various organizational - legal forms of entrepreneurship as cooperatives, mutual societies, associations, social enterprises and organizations, foundations and other existing in different EU member countries entities. Personality in the social economy have cooperatives, enterprises and organizations duly registered under national laws whose business has a social and humanitarian results and they reinvest profits for social purposes. Regarding the criteria for the identification of the entities in the social economy there could be pointed the indicators of the European Parliament to determine the economic and humanitarian activities as part of the social economy (2011a): rule of community and social activity before profit; protection and enforcement of the principles of solidarity and responsibility; reconcile the interests of the participants and the general interest; democratic control by the participants (one member - one vote); voluntary and open membership; self-government and autonomy from government authorities; use a major part of the economic outturn: to follow sustainable development objectives of the company; to meet the specific needs of participants; in favor of the collective interest.

The leading strategic and normative documents define uniformly key elements in the definition of social enterprises (2015-2020):

- Social enterprises pursue profit (socially significant) goals: Social enterprises are created to achieve social objectives (overcoming social injustice and social inequalities of vulnerable groups of people or achieve important public goals in the fields of ecology and sustainable development) and subject its economic activity, in contrast goals of profit in favor of individuals. Social enterprises pursue a direct leading goal to create social benefits in the public interest or for their members.

- Activity that carries out an economic / commercial in nature: The activity of social enterprises is expressed in the provision of goods or services in a competitive market, entrepreneurial way. Very often economic activity covers the delivery of services of general interest (eg social, health, educational, etc.) and very often they are in there essence a social innovation. It is possible that the goods / services are not in themselves directly for the needs of vulnerable groups, but the results or revenues to be in direct benefit or directly to support vulnerable groups and to solve socially significant problem

- Reinvestment of profits from economic activity: All or at least most of the profit of the enterprise is reinvested back into the activity itself (for its expansion or construction fund that also achieves social purpose and which cannot be distributed among individual owners of social businesses or during its existence, or by reason of termination) and not being distributed to private shareholders or owners.

- Institutional independence and inner self-governance: Social enterprises are institutionally independent of the state authorities at central and local level (ie state institutions and municipalities do not have the ability to influence in inner decision-making social enterprises neither by law nor by virtue of its founding documents). Internal management of social enterprises include mechanisms for participation in the decision-making of representatives of vulnerable groups (such as its employees, users, members) for which it exists or the basis of the mechanism of control laid down the principle of social justice. Internal control is based on the principles of representativeness and transparency.

The social enterprise develops in a specific, local context and represents the primary economic unit of the social economy. Social enterprises position themselves between the traditional private and public sectors. The key distinguishing characteristics are social goals, combined with the entrepreneurial potential of the private sector. Social enterprises focus their activities and reinvest profits to achieve social, respectively public purpose, in the interests of its members and the wider range of people.

In the field of employment social enterprises providing services related to: promote employment opportunities and career development for long-term unemployed, people with disabilities and others in the labor market, as well as providing assistance in targeting workplace, providing employment and return to work; promote opportunities for self-employment, entrepreneurship and development of cooperatives and starting one's own business.

The active programs and measures on the labor market are the subject of increasing interest and comment not only because expectations for tangible effects, but also because of the relatively significant financial resources necessary for their implementation. The creation of a model of an active social program, as an instrument of effective social policy, is based on a new approach aimed primarily at securing the effective development of the social object of the program by introducing innovative technologies, optimization of resource flows and broad public participation in development and implementation of programs (2013c; 2015). 
Current study discusses the opportunities and advantages of social entrepreneurship and social enterprises enterprises that aim to provide beneficial social effect against members of vulnerable groups to improve their living standards, employment, provision of services and/or other forms direct support. Social enterprises provide social services for vulnerable consumers, such as access to housing or care, assistance for elderly or disabled, outreach to vulnerable groups, child care, access to employment, education, dealing with addictions and others and as such have the potential to model a significant part of the active social policy.

\section{SOCIAL ENTREPRENEURSHIP AND THE EUROPEAN SOCIAL MODEL}

Social business is a business entirely focused on the creation, operation and development of social enterprises. There are four main ideas for social entrepreneurship. The first idea focuses on risk. The social entrepreneur is a person who acts, decide and satisfy their needs in terms of uncertainties and risks. The second idea focuses on innovative, creative, exploratory nature of social entrepreneurship. The third idea emphasizes the dynamic role of social entrepreneur development of social economy and efficient use of limited social resources. The fourth concept is associated with the social management. According to her, the entrepreneur is constantly looking for change and is an adequate response, maximizing opportunities through innovation.

The social entrepreneur creates social good, not through charity but through action combining economic and social objectives, provides support for socially vulnerable groups of society, promotes social positive change satisfies social needs, optimally uses available resources and apply innovative approaches to the development of social economy.

In the modern European context, the social economy is an established and integral part of social protection and social safety nets, which produces and successfully combines economic profitability and social solidarity. The social economy is a carrier of the democratic values that put people first, creating jobs and promoting active citizenship. The development of the potential of the social economy is dependent on the adequacy of the established political, legislative and operational conditions.

The social economy is a collective concept, which focuses on the direct social impact of the activities of companies and / or organizations that have been established with a social purpose and deliberately organize their activities to achieve such a result. The social economy is both part of the real economy and of civil society in which individuals and/or legal persons, associations of volunteers or other organized entities doing business in the public interest and reinvest profits to achieve social goals (2011a).

Building components of the functional structure of the social economy are: economic function for own resources; social function, realized through the expenditure profile; public policy function of generating public attitudes to social solidarity. In its functional structure, the social economy support the process of social inclusion. The development of social economy is based on cooperative, private, collective socio-economic initiatives based on cooperation and mobilization of resources, trust and mutual aid.

Social economy occupies a specific space between the state (with its defense mechanisms) and the market (with its economic efficiency and focus on profits based on capital). The larger is this space, the greater is the need for the social economy to meet needs that can not be met by existing institutional practices. Social economy serves also as a tool for development of social services; inclusion in the labor market of disadvantaged groups; to improve the functionality of the system of social services; development of local economies and combat poverty and social exclusion. By providing employment to vulnerable groups in society the social economy helps to unite economic and social resources to overcome social exclusion and reduces the risk of poverty and social exclusion, sustainability measures in the field of social policy.

The impact of the social economy in two directions - economic and social. The social benefits are measured by integration and employment of disadvantaged people, with the contribution to the process of social inclusion and the creation of social capital. The most serious economic indicator of the benefits of the social economy are saved public funds for social welfare, on the one hand, and the additional funds offset the social costs of long-term unemployment. Simultaneously, the newly created value in the social economy also represents a significant economic benefit. Additional economic impact of these organizations is their flexibility and ability to mobilize resources from different backgrounds - market and non-market resources, voluntary work and public support.

\section{SOCIAL ENTREPRISES AS A SUSTAINABLE BUSINESS MODEL AND THEIR IMPACT}

Within the social economy a sustainable business model is created that does not qualify in size and areas of activity, but by its respect for common values, such as: the rule of democracy, stronger involvement of civil 
society to achieve social progress, human personality; protection and enforcement of the principles of solidarity and responsibility, combining the interests of its user members with the general interest; democratic control by members; voluntary and open membership; management autonomy and independence in relation to public authorities; use of surplus revenue service members in conjunction with the general interest in achieving the objectives of sustainable development.

Repeatedly it is emphasized that social entrepreneurship plays an important role for social cohesion and the creation of growth and jobs (2013b).

A variety of social enterprises could be identified:

- Private commercial companies that hire people at risk and/or offer products or services for such people;

- Specialized enterprises for people with disabilities who employ these vulnerable groups;

- Non-governmental organizations that develop business within the statutory opportunity to do so or register companies for the development of such activity, providing jobs for people from vulnerable groups;

- Social enterprises to municipalities that employ people from risk groups (mostly of people with disabilities);

- Social enterprises in the form of public-private partnerships with municipalities;

- Day care centers for people with disabilities who are looking for business opportunities with the aim of socialization and adaptation to its clients;

- Social enterprise within a large industrial holding company established for vocational rehabilitation workers received the degree of injury while working at the plant.

This diversity can be perceived and conceptualized in different perspectives. From the standpoint of the working definition, they can be organized into two main groups: Enterprises created as a result of business initiative and operating on a market basis (as we call them "entrepreneurial" type), or enterprises in which dominant is the social cause and profit in the background.

\section{Entrepreneurial type:}

- Specialized enterprises for people with disabilities - the most common type sustainable enterprises.

- Private companies have started their own resources - several cases arising from authentic business idea. They turned out viable precisely because they do not rely on outside help.

- Municipal specialized enterprises for people with disabilities - this is an intermediate type between single specialized enterprises and municipal social enterprises. They remain profit-oriented and actually work on a competitive basis, but in severe financial situations can rely on the support of the municipalities as important, and in some cases major customers.

With a dominant social cause:

- Municipal social enterprises (or public-private partnerships involving the municipality) - the difference with the upper type (local specialized companies) is that leading to them is a social cause (eg, improved living and social status of persons from vulnerable groups - most often people with disabilities). They have no right to separate business income from their activities are not sufficient to finance themselves, ie they are supported mainly by the municipal budget and interruption of funding would not be able to continue their activities. As of this type can be assigned and the only case of an undertaking in a big industrial giant that created it with the aim of vocational rehabilitation workers received the degree of injury while working at the plant. This specific is that the services of a social enterprise is valued, but in practice it can not offer them to external customers and generate revenues.

- Enterprises of non-profit organizations - several major NGOs have their own businesses that offer products on the market and the profit fund their basic social activities. Legally they can function as a separate business entities registered or in the possibility of independent economic activities of NGOs.

- Social services for vulnerable groups seeking further or sustained funding through entrepreneurship, along with employment and socialization - mostly day centers for people with disabilities who work for the inclusion of their clients through their involvement in various activities - most often produce cards, souvenirs, sculptures and more.

Other applicable typology is based on the form of assistance to vulnerable groups. From this perspective, one can distinguish four basic groups of enterprises. 
- Enterprises that create employment / engage people from vulnerable groups to participate in the production process / provision of services, ie they are not passive recipients - social enterprises in Bulgaria are concentrated primarily in this group, which is largely a result of the proliferation of specialized enterprises for people with disabilities;

- Enterprises that offer a standard product / service, but social influence - such as social assistants for sick people, oven in the Roma neighborhood and others. This group is less common than the first;

- Innovative products themselves are related to social assistance or revolutionary social products - a classic example are the computers for the poor in India, an example of such products in Bulgaria are devices to help drive people with disabilities, imported and installed of social enterprise.

- Enterprises that offer free products / services or support financially vulnerable groups - the first historically established form of assistance, this possibility still exists hypothetically. Currently, this form of assistance is typical rather for border areas of social entrepreneurship - corporate social responsibility and charity.

Although the companies of the first group dominate, it should be noted that in some cases there is a combination of more than one form of the support described above. This occurs primarily in new business from an entrepreneurial type.

From the viewpoint of the development phase there could be: social enterprises which are still at the "conceptual design" that need funding and support; social enterprises which are at the beginning of its development; social enterprises in the growth phase; established, stable functioning social enterprises; completed projects in pilot phase that concluded and established social enterprises are in the process of completion or are no longer functioning.

Another classification divides social enterprises in different types depending on their main characteristics:

- Depending on the area in which they work, they are: social enterprises as a provider of social and health services; social enterprises such as training and educational organizations; social enterprises as an employer of persons from marginalized groups or people with disabilities; social enterprises dealing with production and trade.

- Depending on the target groups - social enterprises are oriented to: socially disadvantaged persons; people with physical or mental disabilities; children and families at risk; young people who are not integrated into society (such as orphans); ethnic minorities; women - victims of violence; elderly.

- Depending on your goals social enterprise may have to: economic development - through the creation of employment and wealth creation of target groups; occupational integration of disadvantaged or disabled people, marginalized groups; business orientation and entrepreneurship; social protection.

An important feature of all social enterprises is a special symbiosis that carry a priori - between financial viability and ability to have a social impact. So they achieve simultaneous realization of economic, financial and social objectives, which become even greater value and cost to society.

Typological features of this type of entrepreneurship could be formulated as follows (2013a):

- There is a clear social impact - in the main activity on a balance between the pursuit of profit and direct support to the social status of certain groups.

- There is a clearly defined target group - mainly persons from socially vulnerable groups - those who need help to equalize their life or social status to that of other members of society.

- There is a specific business purpose - is aimed at improving living standards, employment, provision of services and other forms of direct support in order to overcome social exclusion of the target group.

One of the advantages of the social economy is a sufficiency of material resources enjoyed by sources and reserves to which the state has no access. Mobilization of movable and immovable property which is a personal property of volunteers in the process is a prerequisite for market flexibility. Notwithstanding the phenomenal potential of self-logistical provision, social policy of the state should not omit from sight the social economy and the opportunity to promptly allocate such funds, which could prove crucial especially for preservation and development of employment especially in times of crisis. As a rule, social and economic impact of the addition of such resources is very large.

The state monitors the status and development of the social economy and through its competent institutions and experts, primarily through existing social protection systems, supports the entities in the social economy to maintain their capacity and territorial coverage adequate to the level of unemployment and social 
exclusion. Presumably the resources of the entities in the social economy are secured separately by using personal material, financial and labor contributions of the participants in the activities. Depending on the current or prospective social and political reasons, the government grants to certain entities in the social economy target: human resources (through recruitment, through education and training measures); material resources, which also includes the provision of premises and communal services; financial resources. The social economy as an element of the social dialogue is a concept understandable and acceptable by existing social partners to the subject of social dialogue and opportunities of social economy gives the example of resolving social contradictions account functioning both as an employer, employee, investor and owner of businesses.

National policies to promote social enterprises should provide concrete measures regardless of their nature (legal, financial, administrative) must comply and achieve as a result the following principles (2015-2020):

Promotion and sustainability: support for social entrepreneurship should include the release of public funds to support the activities of social enterprises to deal with social problems; planning objectives, procedures and expected results in the provision of public resources to support social enterprises should be based on periodic assessment of the environment, taking into account the peculiarities established at a time models and practices and their potential to work towards social objectives.

Equal treatment and reduce the administrative burden: provide a package of incentives available for all forms of social enterprises; anticipate fast and affordable administrative procedures.

Effectiveness and efficiency: implementation of programs and measures after analyzing the needs consistency and adequacy of goals; relevance of inputs to the result - a clear assessment of the financial and social result.

Coordination and decentralization: establishment of mechanisms for the participation of social enterprises in the planning and evaluation of policy for social entrepreneurship at national level; creation of conditions for development of social entrepreneurship at the local level, according to the specificities and the needs of the territory by involving the municipalities in this process (in local and regional strategies).

Solidarity and partnership: creation of conditions for cooperation, consultations, open dialogue and sharing responsibility among all stakeholders.

\section{CONCLUSION}

Social entrepreneurship is one of the most innovative ways to achieve a better quality of life, independence and inclusion in society of persons from vulnerable groups. In the implementation of active social policies an important role has the social economy and social entrepreneurship in solving the problems of poverty and social exclusion. The potential of social enterprises lies in two of their essential characteristics. First, they act locally networked with multiple stakeholders and knowing well the local problems and they can offer solutions proven to work in a place like reach those groups at risk of poverty or social exclusion to which active social policies reach very rarely in comparison to purely passive assistance. Second, social economy organizations have the potential to mobilize and activate people themselves at risk of poverty and social exclusion and thus enable them to engage themselves in improving their living situation. These two circumstances allot an important place of support of the active policy for the social economy to promote social inclusion.

\section{REFERENCE LIST}

National concept of social economy. Ministry of labor and social policy of the Republic of Bulgaria, Sofia, 2011. (2011a)

Rusanova, L. (2011b). The concept for social entrepreneurship and the Bulgarian experience. Scientific works of the University of Ruse - 2011, Vol. 50, Series 5.1.

Kumanova, M., Shabani, N. (2013a). Analysis of social entrepreneurship in Bulgaria:

Social enterprise and social entrepreneurship. Economic and Social Council of the Republic of Bulgaria, Sofia, (2013b).

Terziev, V. (2013c). The active model of a social programme and its strategic advantage, $12^{\text {th }}$ International Scientific Conference: Management Horizons in Changing Economic Environment \& Visions and 
Challenges, Kaunas, Lithuania.

Road map (2015-2020): Encouragement and development of social enterprises in Bulgaria:

Terziev, V., Stoyanov, E., Arabska, E. (2015). The active social program - an innovative model in social development. Youth forums „Science, technology, innovations, business” 2015 Proceedings.

Research Report about the status and reinforcement of social entrepreneurship in Europe - National report: Bulgaria. Project SESBA: Social Enterprise Skills for Business Advisers, (2016a).

Terziev, V. Arabska, E. (2016b). Social entrepreneurship development in Bulgaria. In: The effectiveness of business management: investments and innovation. Collective monograph. - AMEET Sp. z o.o., Lodz, Poland. 